\title{
Astma w okresie infekcji, ze szczególnym uwzględnieniem pandemii COVID-19
}

\section{Asthma during infection with particular attention to the COVID-19 pandemic}

\author{
Michał Pirożyński \\ Centrum Alergologii, Pneumonologii i Medycyny Ratunkowej, Ośrodek Symulacji CMKP w Warszawie \\ Kierownik: prof. dr hab. med. Michał Pirożyński
}

\section{Streszczenie:}

Od prawie roku żyjemy w warunkach pandemii COVID-19. W listopadzie 2019 r. w Wuhan (Chiny) u coraz większej liczby chorych stwierdzono przypadki ciężkiego śródmiąższowego zapalenia płuc. Czynnikiem etiologicznym okazał się dotychczas niespotykany koronawirus. Nowy wirus, określony mianem SARS-CoV-2, jest blisko spokrewniony z $\beta$-koronawirusem występującym u nietoperzy. Pierwsze doniesienia o nowym schorzeniu zwrócity uwagę na jego podobny przebieg kliniczny do występujących wcześniej chorób wywołanych wirusami SARS w Chinach oraz MERS na Bliskim Wschodzie. Czynnikiem etiologicznym okazały się wówczas wirusy SARS-CoV oraz MERS-CoV. Człowiek nie posiada naturalnej odporności przeciwko tym nowo odkrytym wirusom. Z chwilą, kiedy wirus przeszedł ze swojego naturalnego środowiska (zwierzą) na człowieka, szybkość transmisji zakażenia uległa przyspieszeniu. Do zakażenia najczęściej dochodzi w ciasnych, zamkniętych, żle wentylowanych pomieszczeniach, będących skupiskami dużych grup ludzi. Z wydychanym aerozolem powstałym w drogach oddechowych zakażonego (kichanie, mówienie, śpiew, śmiech, kaszel) wirus przedostaje się do dróg oddechowych kolejnych osób. To spostrzeżenie pozwoliło opracować metody ograniczające kolejne zakażenia do minimum. Pandemia COVID-19 wywołała wiele pytań dotyczących leczenia chorych na astmę i przewlekłą obturacyjną chorobę płuc (POChP) oraz konieczności modyfikacji ich terapii. W związku z podobieństwem objawów pojawiły się pytania o rozpoznanie i odróżnienie COVID-19 od astmy i POChP. Nie jest jasne, czy chorzy na astmę/POChP są narażeni na zwiększone ryzyko zakażenia się SARS-CoV-2. Nie wykazano w dotychczasowych analizach, by choroby alergiczne, astma czy POChP były czynnikami rozwoju infekcji wywołanej przez SARS-CoV-2. Gwałtowny przebieg zakażenia SARS-CoV-2 oraz wywołany tym zakażeniem zespół burzy cytokinowej (CSS, cytokine storm syndrome), który charakteryzuje się podwyższonymi markerami stanu zapalnego (np. CRP, ferrytyny), a także nabyty niedobór odporności (limfopenia z redukcją komórek T) budzą obawy dotyczące zaostrzeń zapalenia alergicznego w drogach oddechowych. Ponadto zakłócenie kaskady koagulacyjnej w CSS może prowadzić do koagulopatii z podwyższonym poziomem D-dimerów oraz zaburzeniami metabolizmu fibryny (uogólnionej ciężkiej choroby wewnątrznaczyniowej), co jest uwidocznione w analizowanych parametrach hematologicznych chorych na COVID-19. Nasilenie zmian zachodzących w miąższu płuc może być wywołane postępującymi zaburzeniami układu koagulacyjnego oraz zmianami w drobnych naczyniach występujących nie tylko w płucach, ale również w naczyniach nerek, serca i mózgu. Starszy wiek oraz choroby wspótistniejące u pacjentów z tej grupy wiekowej, czyli: choroby serca, nadciśnienie tętnicze, POChP, astma, cukrzyca i otyłość, to czynniki ryzyka cięższego przebiegu COVID-19. Istnieją jednak kontrowersje dotyczące wpływu astmy oraz POChP na przebieg COVID-19. Obecne zalecenia CDC (Centers for Disease Control and Prevention, USA) wskazują, że pacjenci z umiarkowanym/ciężkim przebiegiem astmy mogą być bardziej narażeni na cięższy przebieg choroby w przypadku zakażenia SARS-CoV-2. Należy pamiętać, że dzieci są najmniej narażone na zakażenie SARS-CoV-2, a to z powodu mniejszej ekspresji receptora ACE-2 oraz TMPRSS2 $w$ drogach oddechowych w porównaniu z dorosłymi. Podstawą terapii kontrolującej w przypadku astmy są wziewne glikokortykosteroidy (wGKS). Glikokortykosteroidy oddziałujące bezpośrednio na nabłonek oddechowy przyczyniają się do zmniejszania reakcji zapalnych poprzez wzrost stężenia cytokin o działaniu przeciwzapalnym. Istotnym elementem w zakażeniu SARS-CoV-2 są receptory ACE-2 obecne na powierzchni komórek nabłonka oddechowego. Tych receptorów jest mniej w przypadku astmy alergicznej, co oznacza, że wirusy SARS-CoV-2 mają mniejszą zdoIność łączenia się z tymi komórkami. W badaniach przedklinicznych wykazano również, że niektóre substancje stosowa- 
ne w leczeniu astmy zmniejszają replikację wirusa SARS-CoV-2 w komórkach nabłonka oddechowego. Wziewne glikokortykosteroidy zmniejszają ciężkość zakażenia SARS-CoV-2 u chorych na POChP. Wykazano również, że leki: glikopironium, formoterol oraz potrójny lek łączony zawierający budezonid, formoterol i glikopironium, hamują replikację koronawirusa oraz zmniejszają syntezę cytokin prozapalnych. Podobne obserwacje poczyniono w przypadku zakażeń rinowirusem. Nie tylko chorzy na astmę, ale również na POChP nie powinni przerywać terapii lekami inhalacyjnymi, zwłaszcza glikokortykosteroidami, w okresie pandemii SARS-CoV-2. W POChP długo działające leki rozszerzające oskrzela ( $\beta$-mimetyki: formoterol, salmeterol; cholinolityki: glikopironium, tiotropium) są I linią terapii. W przypadku chorych, u których obserwujemy częste zaostrzenia, dodanie wGKS podczas tych zaostrzeń, a następnie wprowadzenie doustnych glikokortykosteroidów oraz antybiotyków powinno być naturalnym działaniem w przebiegu zakażenia SARS-CoV-2. Stosując leki w nebulizacji, należy zachować wszelkie zasady bezpieczeństwa. Nie ma wskazań do zamiany nebulizacji na leczenie za pomocą pMDI. U chorych leczonych DPI powinno się stosować inhalatory wielodawkowe, bezpieczniejsze od jednorazowych (kapsułkowych).

\section{Abstract:}

For almost a year now, we have been living during the COVID-19 pandemic. In November 2019, an increasing number of patients were diagnosed with severe interstitial pneumonia in Wuhan (China). A new coronavirus, previously unknown in humans, SARS-CoV-2, turned out to be an etiological factor. The new virus called SARS-CoV-2 is closely related to the $\beta$-coronavirus found in bats. The first cases of the new disease have highlighted a similar clinical course of interstitial pneumonias previously found in China and the Middle East (SARS and MERS). The SARS-CoV and MERS-CoV viruses turned out to be etiological factors. Man has no natural immunity against these newly discovered viruses. As soon as the virus has passed from its natural environment (animals) to man, the transmission rate of the infection has accelerated. Most often the infection occurs in tightly closed, poorly ventilated rooms, which are clusters of large groups of people. With the exhaled aerosol formed in the airways of the infected person (sneezing, talking, singing, laughing, coughing) the virus enters the airways of subsequent people. This observation allowed to develop methods to reduce subsequent infections to a minimum. Pandemic COVID-19 raised many questions about the treatment of asthma/ COPD patients and the need to modify their treatment. Due to the similarity of symptoms, questions arose about the diagnosis and differentiation of COVID-19 from asthma/COPD. It is unclear whether patients with asthma/COPD are at increased risk of SARS-CoV-2 infection. It has not been shown in previous analyses that allergic diseases, asthma or COPD are factors in the development of infection caused by SARS-CoV-2. However, the turbulent course of SARS-CoV-2 infection and the cytokine storm syndrome (CSS) caused by this infection, which is characterized by elevated inflammatory markers (e.g., CRP, ferritin) and acquired immunodeficiency (lymphopenia with T-cell reduction) raise concerns about exacerbation of allergic inflammation in the airways. Moreover, disruption of the coagulation cascade in CSS may lead to coagulopathy with elevated D-dimers and fibrin metabolism disorders (generalized severe endovascular disease), which is reflected in the analyzed hematological parameters of COVID-19 patients. Increased lesions in the lung parenchyma may be caused by progressive disorders of the coagulation system, but also changes in small vessels occurring not only in the lungs, but also in the vessels of the kidneys, heart and brain. Older age and coexisting diseases for patients in this age group - heart disease, hypertension, chronic obstructive pulmonary disease (COPD), asthma, diabetes mellitus and obesity are risk factors for the more severe course of COVID-19. However, there is controversy about the influence of asthma and COPD on the course of COVID-19. Current recommendations of the CDC (Centers for Disease Control and Prevention - USA) state that patients with moderate to severe asthma may be more likely to develop a more severe disease if they are infected with SARS-CoV-2. It should be remembered that children are the least exposed to SARS-CoV-2 infection due to lower ACE-2 and TMPRSS2 receptor expression in the airways compared to adults. The basis of control therapy for asthma is inhalation steroids. Steroids interact directly with the respiratory epithelium, contributing to the reduction of inflammatory reactions through the growth of anti-inflammatory cytokines. An important element in SARS-CoV-2 infection are ACE-2 receptors present on the surface of respiratory epithelial cells. There are fewer of these receptors in allergic asthma, which means that SARS-CoV-2 viruses have less ability to connect to these cells. Preclinical studies have also shown that some substances used to treat asthma reduce the replication of SARS-CoV-2 in respiratory epithelial cells. Inhalational steroids reduce the severity of SARS-CoV-2 infection in COPD patients. It has also been shown that medications - glycopyronium, formoterol and triple combination drug containing budesonide, formoterol and glycopyronium inhibit coronavirus replication and reduce the synthesis of proinflammatory cytokines. Similar observations have been made in the case of rhinovirus infections. Not only asthma patients but also COPD patients should not interrupt their treatment with inhalation drugs, especially steroids during the SARS-CoV-2 pandemic. In COPD long-acting bronchodilators ( $\beta$-mimetics - formoterol, salmeterol, cholinolytics - glycopyronium, tiotropium) are the first line of therapy. The addition of inhalation glucocorticosteroid in patients with frequent exacerbations during these exacerbations, followed by the introduction of oral corticosteroids and antibiotics, should be a natural effect in the course of SARS-CoV-2 infection. All safety rules should be observed when using drugs in nebulization. There are no indications to replace nebulization with pMDI. In patients treated with DPI, multi-dose inhalers should be used, safer than single dose (capsule) ones.

Słowa kluczowe: astma, leczenie inhalacyjne, COVID-19

Key words: asthma, inhalation therapy, COVID-19 


\section{Wstęp}

Od prawie roku trwa pandemia COVID-19. W listopadzie 2019 r. w Wuhan (Chiny) u coraz większej liczby chorych stwierdzono przypadki ciężkiego śródmiąższowego zapalenia płuc. Czynnikiem etiologicznym okazał się nowy koronawirus, dotychczas niespotykany u ludzi, który nazwano SARS-CoV-2 [1]. Do 29 listopada 2020 r. na całym świecie rozpoznano 62882389 przypadków zakażenia tym wirusem. W listopadzie br. ogólnie nowych przypadków notowano ponad 600 tys. dziennie, a w tym samym okresie umierało ok. 10 tys. chorych [2].

SARS-CoV-2 jest blisko spokrewniony z $\beta$-koronawirusem stwierdzanym $u$ nietoperzy [3]. Pierwsze przypadki nowego schorzenia zwróciły uwagę na jego podobny przebieg kliniczny do śródmiąższowych zapaleń płuc odnotowywanych wcześniej w Chinach i na Bliskim Wschodzie (SARS oraz MERS). Czynnikiem etiologicznym okazały się wtedy wirusy SARS-CoV i MERS-CoV [1].

Człowiek nie posiada naturalnej odporności przeciwko tym nowo odkrytym wirusom. Z chwilą, kiedy wirus przeszedł ze swojego naturalnego środowiska (zwierząt) na człowieka, szybkość transmisji zakażenia uległa przyspieszeniu. Do zakażenia najczęściej dochodzi w ciasnych, zamkniętych, źle wentylowanych pomieszczeniach, w których przebywa dużo ludzi. To spostrzeżenie pozwoliło opracować metody ograniczające kolejne zakażenia do minimum. Stąd ograniczenia liczby osób przebywających w jednym pomieszczeniu, ograniczenia imprez masowych oraz wszelkich zgromadzeń w zamkniętych pomieszczeniach. Zakażenie przenosi się drogą kropelkową, kiedy wdychamy aerozol zakażonej osoby powstały w trakcie mówienia, śpiewu, śmiechu, krzyku, kichania czy też kaszlu. Założenie przegrody (maski) dla wydalanego oraz wdychanego aerozolu, a także dokładne mycie rąk pozostają głównymi metodami zapobiegania transmisji zakażenia [4]. Należy pamiętać, że skuteczność działania tej przegrody nie jest identyczna w każdym przypadku - najbardziej efektywne pozostają maski medyczne, przyłbice są w zasadzie nieskuteczne [4].

W trakcie głośnego mówienia, kaszlu, kichania aerozol wytworzony przez zakażonego przenosi się na odległość 1-5 m. Jak wykazano w badaniach symulacyjnych, może się przenieść nawet na odległość $6 \mathrm{~m}$. Zatem dystansowanie się, utrzymywanie odległości $>1,5 \mathrm{~m}$ jest jak najbardziej zasadne [4].

\section{COVID-19 a astma i przewlekła obturacyjna} choroba płuc

Pandemia COVID-19 wywołała wiele pytań dotyczących leczenia chorych na astmę i przewlekłą obturacyjną chorobę płuc (POChP) oraz konieczności modyfikacji ich terapii. W związku z podobieństwem objawów pojawiły się pytania o rozpoznanie COVID-19 i odróżnienie tej choroby od astmy i POChP. Nie jest jasne, czy chorzy na astmę/POChP są narażeni na zwiększone ryzyko zakażenia się SARS-CoV-2.

Pierwsze przypadki COVID-19 w Europie jednoznacznie powiązano $\mathrm{z}$ zarażeniem od osób przybyłych z Chin, u których występował bezobjawowy przebieg choroby. Obecnie obserwujemy zakażenia nie tylko od osób przybyłych z regionów o wysokiej zachorowalności, ale również od tych, które w tych regionach nigdy nie były, a doświadczyły jedynie kontaktu z osobami bezobjawowymi lub skąpo objawowymi [5].

Nie wykazano w dotychczasowych analizach, by choroby alergiczne, astma czy POChP były czynnikami rozwoju infekcji wywołanej przez SARS-CoV-2 [6]. Gwałtowny przebieg zakażenia SARS-CoV-2 i wywołany tym zakażeniem zespół burzy cytokinowej (CSS, cytokine storm syndrome), który charakteryzuje się podwyższonymi markerami stanu zapalnego (np. CRP, ferrytyny), oraz nabyty niedobór odporności (limfopenia $\mathrm{z}$ redukcją komórek T) budzą obawy zaostrzeń zapalenia alergicznego w drogach oddechowych [7]. Ponadto zakłócenie kaskady koagulacyjnej w CSS może prowadzić do koagulopatii z podwyższonym poziomem D-dimerów oraz zaburzeniami metabolizmu fibryny (uogólnionej ciężkiej choroby wewnątrznaczyniowej), co jest uwidocznione w analizowanych parametrach hematologicznych chorych na COVID-19 [8]. Nasilenie zmian zachodzących w miąższu płuc może być wywołane postępującymi zaburzeniami układu koagulacyjnego i zmianami w drobnych naczyniach występujących nie tylko w płucach, ale również w naczyniach nerek, serca oraz mózgu [9].

Starszy wiek, a także choroby współistniejące u osób z tej grupy wiekowej: choroby serca, nadciśnienie tętnicze, POChP, astma, cukrzyca i otyłość, to czynniki ryzyka dla cięższego przebiegu COVID-19 [10]. Istnieją jednak kontrowersje dotyczące wpływu astmy oraz POChP na przebieg COVID-19. Obecne zalecenia CDC (Center for Diseases Control and Prevention, USA) wskazują, że pacjenci z umiarkowanym/ ciężkim przebiegiem astmy mogą być bardziej narażeni na cięższą chorobę w przypadku zakażenia SARS-CoV-2. Należy pamiętać, że dzieci są najmniej narażone na zakażenie SARS-CoV-2, a to z powodu mniejszej 
ekspresji receptora ACE-2 oraz TMPRSS2 w drogach oddechowych w porównaniu z dorosłymi [11].

Astma należy do najczęściej występujących schorzeń alergicznych. Szacuje się, że cierpi na nią 8-9\% populacji [12], dlatego wydawałoby się, że choroby obturacyjne (astma, POChP) mogą stanowić istotne ryzyko zakażenia SARS-CoV-2. Jednak liczba chorych na astmę i POChP w pracach z ośrodków z Chin oraz Włoch była znacznie niższa niż oczekiwano, uwzględniając częstość ich występowania, i wahała się między $1,5 \%$ a $4 \%$ [6, 13-16]. Zupełnie odmienne dane przytaczano z Nowego Jorku oraz Wielkiej Brytanii. Wśród pacjentów z COVID-19 w Nowym Jorku było 9\% chorych na astmę oraz 5,4\% na POChP, w Wielkiej Brytanii aż 14\% [16].

W ostatnim okresie pojawia się coraz więcej informacji, że astma nie jest czynnikiem ryzyka gorszego klinicznego przebiegu zakażenia SARS-CoV-2, w tym ryzyka zgonu [17]. Barroso i wsp. w swojej analizie stwierdzili, że długość hospitalizacji z powodu zakażenia SARS-CoV-2 chorych na astmę nie różni się od długości hospitalizacji pacjentów bez współistniejącej astmy $(9,72 \pm 8,14$ dnia vs 10,9 $\pm 9,67$ dnia) [18]. Chhiba i wsp. wykazali, że astma nie przyczynia się do większego ryzyka hospitalizacji z powodu COVID-19 [19]. Wykazano również, że astma ani nie wydłuża okresu hospitalizacji z powodu COVID-19, ani nie przyczynia się do ryzyka hospitalizacji na oddziale intensywnej terapii [20]. Ponadto współistniejąca astma nie wpływa na zwiększoną częstość koniecznej intubacji, czas trwania intubacji ani na rozwój zespołu ostrej niewydolności oddechowej (ARDS, acute respiratory distress syndrome) w przebiegu zakażenia SARS-CoV-2 u tych chorych [20].

Wiadomo zatem, że sama astma nie oddziałuje na zwiększone ryzyko zachorowania na COVID-19 ani współistniejąca astma nie ma wpływu na ciężkość rozwoju zakażenia SARS-CoV-2 [21]. Stwierdzono wręcz, że cytokiny typu II reakcji zapalnej (IL-4, IL-5) oraz gromadzenie się granulocytów kwasochłonnych przeciwdziałają rozwojowi zakażenia SARS-CoV-2 [22-24]. Wykazano również, że u chorych na astmę obserwujemy zmniejszoną ekspresję receptorów ACE-2, kluczowych dla łączenia się wirusa z nabłonkiem oddechowym [21]. Spostrzeżenie to nie dotyczy jednak chorych na astmę niealergiczną [25].

Nie wykazano, by astma ciężka, kwalifikująca się do leczenia biologicznego, była czynnikiem ryzyka ciężkiego przebiegu COVID-19, jak również by istniała konieczność prewencyjnej hospitalizacji chorych na zaostrzenie astmy na oddziałach intensywnej terapii $[26,27]$. Jednym z czynników zmniejszających ryzyko hospitalizacji chorych na astmę w przebiegu zakażenia SARS-CoV-2 jest stosowanie glikokortykosteroidów wziewnych (wGKS) [28].

Czynnikiem, który może się przyczynić do gorszego przebiegu zakażenia SARS-CoV-2 u chorych na astmę, jest jej zła kontrola. Zmniejszenie dobowej dawki wGKS przyczynia się m.in. do gorszej wymiany gazów w pęcherzykach płucnych. Nadmierne wydzielanie śluzu i zmniejszanie przepływu powietrza do jednostek wymiany gazowej mogą pogłębiać hipoksemię wywołaną rozlanym uszkodzeniem pęcherzyków płucnych w przebiegu zakażenia SARS-CoV-2 [21, 24, 29].

Wiadomo, że infekcje koronawirusami mogą wywoływać zaostrzenie astmy, zatem zakażenie SARS-CoV-2 może przyczyniać do nasilenia zmian zapalnych i hipersekrecji śluzu [21]. Wykazano jednak, że wirusy SARS i MERS nie wywołują takich zaostrzeń [30]. Ponadto Grandbastien i wsp. nie potwierdzili, by zakażenia SARS-CoV-2 przyczyniały się do zaostrzeń astmy [20]. Te przeciwstawne obserwacje podkreślają konieczność utrzymania terapii kontrolującej w przypadku wszystkich pacjentów z obturacyjną chorobą płuc.

Podstawą terapii kontrolującej w przypadku astmy są wziewne glikokortykosteroidy. Glikokortykosteroidy oddziałujące bezpośrednio na nabłonek oddechowy przyczyniają się do zmniejszania reakcji zapalnych poprzez wzrost cytokin o działaniu przeciwzapalnym [21]. Istotnym elementem w zakażeniu SARS-CoV-2 są receptory ACE-2 obecne na powierzchni komórek nabłonka oddechowego. Tych receptorów jest mniej w przypadku astmy alergicznej, co oznacza, że wirusy SARS-CoV-2 mają mniejszą zdolność łączenia się z tymi komórkami [21]. W badaniach przedklinicznych wykazano również, że niektóre substancje stosowane w leczeniu astmy zmniejszają replikację wirusa SARS-CoV-2 w komórkach nabłonka oddechowego [1]. Matsuyama i wsp. wykazali, że jeden z glikokortykosteroidów wziewnych powszechnie stosowany w leczeniu astmy zmniejsza replikację SARS-CoV-2 w komórkach nabłonka oddechowego [31]. Wziewne glikokortykosteroidy zmniejszają ciężkość zakażenia SARS-CoV-2 u chorych na POChP [32]. Wykazano również, że leki: glikopironium, formoterol oraz potrójny lek łączony zawierający budezonid, formoterol i glikopironium, hamują replikację koronawirusa oraz zmniejszają syntezę cytokin prozapalnych [1, 21, 33]. Podobne obserwacje poczyniono w przypadku zakażeń rinowirusem [34].

Wiadomo zatem, że w przypadku zakażenia wirusem SARS-CoV-2 u chorych na astmę oraz POChP nie należy przerywać stosowania leków inhalacyjnych. 
Istnieją dowody sugerujące, że pandemia może zwiększyć adherencję na leki inhalacyjne stosowane zarówno w astmie, jak i POChP [16]. Paradoksalnie może się okazać, że pandemia może poprawić skuteczność kliniczną leczenia chorób obturacyjnych, głównie dzięki zwiększonej dyscyplinie tej grupy chorych (m.in. w noszeniu maseczek, utrzymywaniu dystansu społecznego) oraz zwiększonej adherencji w przyjmowaniu leków inhalacyjnych [16].

Czy pandemia może mieć wpływ na pacjentów $\mathrm{z}$ chorobami obturacyjnymi płuc (astma, POChP)? Istnieją sprzeczne doniesienia na ten temat. W Hiszpanii wykazano, że pandemia marginalnie wpłynęła na jakość leczenia chorych na POChP [35]. Z powodu pandemii i lockdownu zmniejszyła się tam liczba chorych przyjmowanych przez lekarzy POZ, jak również przez szpitalne oddziały ratunkowe $\mathrm{z}$ powodu zaostrzeń tych schorzeń. Być może właśnie z powodu lockdownu dochodzi do zmniejszenia ekspozycji chorych na wirusy i bakterie, co z kolei osłabia zaostrzenia chorób obturacyjnych, zwłaszcza POChP. Do tego przyczynia się również ewidentna redukcja smogu w okresie pandemii w dużych europejskich miastach [36].

Jak wspomniano, pandemia marginalnie wpływa na przebieg kliniczny POChP. Czy i w jaki sposób COVID-19 oddziałuje na przebieg ciężkiej POChP? Mechanizm interakcji nie jest dokładnie poznany. Wiadomo, że pierwszym miejscem zetknięcia SARS-CoV-2 z człowiekiem jest błona śluzowa nosa. W nosie znajduje się bardzo dużo receptorów ACE-2 - są one miejscem łączenia się glikoproteiny $\mathrm{S}$ wirusa SARS-CoV-2 z komórkami nabłonka oddechowego, dzięki któremu wirus wnika do wnętrza komórki. Z chwilą wniknięcia dochodzi do jego replikacji i wytworzenia setek nowych wirionów. Wiriony uwalniane z zakażonych komórek do przestrzeni międzykomórkowej oraz do płynu wyścielającego drogi oddechowe zakażają sąsiednie komórki oraz są przenoszone do obwodowych dróg oddechowych. Zostało już potwierdzone, że u chorych na POChP stwierdzamy wyższą ekspresję receptorów ACE-2, zwłaszcza w obwodowych drogach oddechowych $[11,37]$. Chorzy na POChP mogą zatem być bardziej podatni na zakażenie SARS-CoV-2 oraz rozwijanie cięższego przebiegu zakażenia koronawirusem. Ciekawe spostrzeżenie wynikło z pracy Attaway i wsp. Wykazano w niej, że u chorych na POChP leczonych wGKS występuje mniejsze ryzyko zachorowania na COVID-19. Stwierdzenie zakażenia SARS-CoV-2 było mniej prawdopodobne (2,4 razy mniej) u pacjentów otrzymujących wGKS. Wynik dodatni był rzadziej stwierdzany u chorych leczonych wGKS w porównaniu $\mathrm{z}$ chorymi nieleczonymi glikokortykosteroidami
$(18,3 \%$ vs 44,8\%; p < 0,001) [38]. Jest to powód do stwierdzenia, że wGKS również w populacji chorych na POChP działają ochronnie, zmniejszając intensywność replikacji wirusów SARS-CoV-2 w drogach oddechowych [39]. To oznacza również, że nie tylko chorzy na astmę, ale i na POChP nie mogą przerywać terapii lekami inhalacyjnymi, zwłaszcza glikokortykosteroidami, w okresie pandemii SARS-CoV-2. W POChP długo działające leki rozszerzające oskrzela ( $\beta$-mimetyki: formoterol, salmeterol; cholinolityki - glikopironium, tiotropium) są I linią terapii. Dodanie wGKS u chorych, u których obserwujemy częste zaostrzenia, podczas tych zaostrzeń, a następnie wprowadzenie doustnych glikokortykosteroidów oraz antybiotyków powinno być naturalnym działaniem w przebiegu zakażenia SARS-CoV-2 [40].

\section{Inhalacje w dobie pandemii COVID-19}

Wiemy, że nie należy przerywać leczenia inhalacyjnego u chorych na astmę/POChP w okresie pandemii COVID-19. Czy jednak wszystkie metody leczenia inhalacyjnego mogą być stosowane? W czasie poprzednich epidemii spowodowanych koronawirusami - SARS, MERS - wprowadzono zakazy stosowania terapii inhalacyjnej, głównie w szpitalach i ośrodkach służby zdrowia [41]. Zalecenia oparto na wynikach obserwacji, że sama intubacja oraz wymuszona wentylacja przyczynia się do zwiększenia ryzyka zakażenia (odpowiednio 6,6- i 3,3-krotnego) u pracowników służby zdrowia [42]. Na tej podstawie stwierdzono, że skoro intubacja i/lub wymuszona wentylacja przyczyniają się do zwiększonej emisji zakażonych cząstek z dróg oddechowych, to również nebulizacja wprowadzająca aerozol do układu oddechowego zwiększa ryzyko zakażenia. Pominięto to, że w tej samej analizie, oceniwszy zwiększenie ryzyka zakażenia nadzorujących nebulizację, stwierdzono, że wynosi ono jedynie 0,9. Czyli sama nebulizacja nie wpływa na zwiększenie ryzyka zachorowania wśród pracowników służby zdrowia. Niemniej jednak z chwilą ustalenia, że nebulizacja niesie za sobą zwiększenie ryzyka zachorowania na choroby zakaźne (takie jak: SARS, MERS, COVID-19), liczne organizacje wykazały w swoich analizach, że należy tę metodę zastąpić innymi technikami wykorzystującymi inhalatory - pMDI (pressurised metered dose inhalers), DPI (dry powder inhalers). Jednocześnie nie przedstawiono żadnych dowodów na zasadność takiego postępowania [41]. Uważano, że potencjalnie największe niebezpieczeństwo istnieje w przypadku nebulizatorów pneumatycznych. Budowa tych nebulizatorów przyczynia się do gromadzenia roztworu/zawiesiny leku w komorze 
nebulizacyjnej w trakcie wydechu chorego, co sprzyja skażeniu wdychanego przez niego roztworu/zawiesiny. Również roztwór wydychany sprzyja przedostawaniu się bioaerozoli na zewnątrz, stanowiąc zagrożenie dla samego chorego oraz jego opiekunów [43]. Na poglądy te miał wpływ sposób produkcji inhalatorów wytwarzanych jako pojedyncze zamknięte pojemniki (pMDI) zawierające sterylny roztwór. Dawka precyzyjnie odmierzona zawierała wyłącznie sterylny roztwór. Wytwarzany aerozol o małej objętości i krótkim czasie utrzymywania się charakteryzuje się bardzo niskim prawdopodobieństwem wtórnego skażenia. Jednak już dołączenie komory inhalacyjnej zwiększa ryzyko zakażenia, zwłaszcza gdy jest ona źle przygotowana do użycia (nieumyta, niezdezynfekowana) [41, 43]. Komora nebulizacyjna natomiast po zastosowaniu musi być myta, dezynfekowana i przechowywana w zamkniętym opakowaniu.

Powróćmy do nebulizacji. Czy powinna być ona rzeczywiście zaniechana w dobie pandemii? Wiele osób wypowiadało się już na ten temat, twierdząc, że nie ma dowodów na takie postępowanie. Nebulizacja przy zastosowaniu odpowiednich procedur jest całkowicie bezpieczna zarówno w placówkach służby zdrowia, jak i w warunkach domowych [44, 45]. Światowa Organizacja Zdrowia (WHO, World Health Organization) wycofała się z wcześniej wygłaszanych poglądów.

Jedynie w sytuacji, gdy wlany lek jest skażony, możemy mieć do czynienia z inhalowaniem skażonego roztworu. Trzeba zachować szczególną ostrożność przy wlewaniu roztworów/zawiesin do nebulizatora. Nigdy nie należy używać leku wcześniej przygotowanego do zastosowania. Lek powinien być przygotowywany bezpośrednio przed inhalacją.

W okresie pandemii COVID-19 wielodawkowe inhalatory suchego proszku (mdDPI, multidose dry powder inhaler) są zdecydowanie najbezpieczniejszymi inhalatorami. W przeciwieństwie do kapsułkowych jednodawkowych inhalatorów (DPI, dry powder inhaler) chory nie dotyka leku, który jest inhalowany, zatem ryzyko skażenia jest minimalne.

Leki dostępne w mdDPI (budezonid, salbutamol, formoterol i inne) rzadko prowokują do napadu kaszlu bezpośrednio po inhalacji, tym samym zmniejszając ryzyko gwałtownej emisji bioaerozoli z dróg oddechowych osoby zakażonej [1].

\section{Podsumowanie}

W okresie pandemii COVID-19 nie należy przerywać terapii inhalacyjnej $\mathrm{u}$ chorych na astmę i POChP. Stosując leki w nebulizacji, powinno się zachować wszelkie zasady bezpieczeństwa. Nie ma wskazań do zamiany nebulizacji na leczenie chorych za pomocą pMDI. U pacjentów leczonych DPI należy stosować inhalatory wielodawkowe, które są bezpieczniejsze od jednorazowych (kapsułkowych). Nie należy również przerywać leczenia glikokortykosteroidami wziewnymi, które zmniejszają replikację wirusów (korona-, rinowirusów) w drogach oddechowych.

\section{Piśmiennictwo}

1. Pirożyński M. Terapia wziewna - ze szczególnym uwzględnieniem steroidów - w okresie pandemii COVID-19. Alergia. 2020; 1: 4-6.

2. COVID-19 CORONAVIRUS PANDEMIC. http://www.worldometers.info/coronavirus/? (access: 21.11.2020).

3. Hsu LY, Chia PY, Lim JF. The Novel Coronavirus (SARS-CoV-2) Epidemic. Ann Acad Med Singapore. 2020; 49(1): $1-3$.

4. Verma S, Dhanak M, Frankenfield J. Visualizing the effectiveness of face masks in obstructing respiratory jets. Phys Fluids. (1994). 2020; 32(6): 061708.

5. Rothe C, Schunk M, Sothmann P et al. Transmission of 2019- $n$ CoV Infection from an Asymptomatic Contact in Germany. NEngl J Med. 2020; 382(10): 970-1.

6. Zhang JJ, Dong X, Cao YY et al. Clinical characteristics of 140 patients infected with SARS-CoV-2 in Wuhan, China. Allergy. 2020; 75(7): 1730-41.

7. Panettieri RA Jr., Carson J, Horton D et al. Asthma and COVID: What Are the Important Questions? J Allergy Clin Immunol Pract. 2020; 8(8): 2487-8.

8. Fan BE, Chong VCL, Chan SSW et al. Hematologic parameters in patients with COVID-19 infection. Am J Hematol. 2020; 95(6): E131-E134.

9. Peters MC, Sajuthi S, Deford P et al. COVID-19-related Genes in Sputum Cells in Asthma. Relationship to Demographic Features and Corticosteroids. Am J Respir Crit Care Med. 2020; 202(1): 83-90.

10. Zhou F, Yu T, Du R et al. Clinical course and risk factors for mortality of adult inpatients with COVID-19 in Wuhan, China: a retrospective cohort study. Lancet. 2020; 395(10229): 1054-62.

11. Saheb Sharif-Askari N, Saheb Sharif-Askari F, Alabed M et al. Airways Expression of SARS-CoV-2 Receptor, ACE2, and TMPRSS2 Is Lower in Children Than Adults and Increases with Smoking and COPD. Mol Ther Methods Clin Dev. 2020; 18: 1-6.

12. Global Initiative for Asthma. Global Strategy for Asthma Management and Prevention. 2020. www.ginaasthma.org (access: 21.11.2020). 
13. Feng Y, Ling Y, Bai T et al. COVID-19 with Different Severities: A Multicenter Study of Clinical Features. Am J Respir Crit Care Med. 2020; 201(11): 1380-8.

14. Yang J, Zheng Y, Gou X et al. Prevalence of comorbidities and its effects in patients infected with SARS-CoV-2: a systematic review and meta-analysis. Int J Infect Dis. 2020; 94: 91-5.

15. García-Pachón, E, Zamora-Molina L, Soler-Sempere MJ et al. Asthma and COPD in Hospitalized COVID-19 Patients. Arch Bronconeumol. 2020; 56(9): 604-6.

16. Kaye L, Theye B, Smeenk I et al. Changes in medication adherence among patients with asthma and COPD during the COVID-19 pandemic. J Allergy Clin Immunol Pract. 2020; 8(7): 2384-5.

17. Wang Y, Chen J, Chen $W$ et al. Does Asthma Increase the Mortality of Patients with COVID-19?: A Systematic Review and Meta-Analysis. Int Arch Allergy Immunol. 2020: 1-7.

18. Barroso B, Valverde-Monge M, Cañas Jose A et al. Prevalence, Characteristics, and Outcome of Asthmatic Patients With Type 2 Diseases in Hospitalized Patients With COVID-19 in Madrid, Spain. J Investig Allergol Clin Immunol. 2020; 30(5): 382-4.

19. Chhiba KD, Patel GB, Vu THT et al. Prevalence and characterization of asthma in hospitalized and nonhospitalized patients with COVID-19. J Allergy Clin Immunol. 2020; 146(2): 307-314.e4.

20. Grandbastien M, Piotin A, Godet $J$ et al. SARS-CoV-2 Pneumonia in Hospitalized Asthmatic Patients Did Not Induce Severe Exacerbation. J Allergy Clin Immunol Pract. 2020; 8(8): 2600-7.

21. Hughes-Visentin A, Paul ABM. Asthma and COVID-19: What do we know now. Clin Med Insights Circ Respir Pulm Med. 2020; 14: 1179548420966242.

22. Liu S, Zhi Y, Ying S. COVID-19 and Asthma: Reflection During the Pandemic. Clin Rev Allergy Immunol. 2020; 59(1): 78-88.

23. Carli G, Cecchi L, Stebbing J et al. Asthma phenotypes, comorbidities, and disease activity in COVID-19: The need of risk stratification. Reply to Morais-Almeida. Allergy. 2020. (w druku).

24. Carli G, Cecchi L, Stebbing J et al. Is asthma protective against COVID-19? Allergy. 2020 (w druku).

25. Jackson DJ, Busse WW, Bacharier LB et al, Association of respiratory allergy, asthma, and expression of the SARS-CoV-2 receptor ACE2. J Allergy Clin Immunol. 2020; 146(1): 203$-206 . e 3$.

26. Rial MJ, Valverde M, Del Pozo V et al. Clinical characteristics in 545 patients with severe asthma on biological treatment during the COVID-19 outbreak. J Allergy Clin Immunol Pract. 2020 (w druku).

27. Robinson LB, Fu Y, Bassett IV et al. COVID-19 severity in hospitalized patients with asthma: A matched cohort study. J Allergy Clin Immunol Pract. 2020 (w druku).
28. Rogliani P, Lauro D, di Daniele $N$ et al. Reduced risk of COVID-19 hospitalization in asthmatic and COPD patients: a benefit of inhaled corticosteroids? Expert Rev Respir Med. 2020 ( w druku).

29. Konopka KE, Wilson A, Myers JL. Postmortem Lung Findings in a Patient With Asthma and Coronavirus Disease 2019. Chest. 2020; 158(3): e99-e101.

30. Pennington E. Asthma increases risk of severity of COVID-19. Cleve Clin JMed. 2020 (w druku).

31. Matsuyama S, Kawase M, Nao $N$ et al. The inhaled steroid ciclesonide blocks SARS-CoV-2 RNA replication by targeting the viral replication-transcription complex in cultured cells. J Virol. 2020 (w druku).

32. Finney LJ, Glanville N, Farne $H$ et al. Inhaled corticosteroids downregulate the SARS-CoV-2 receptor ACE2 in COPD through suppression of type I interferon. J Allergy Clin Immunol. 2020 (w druku).

33. Yamaya $M$, Nishimura $H$, Deng $X$ et al. Inhibitory effects of glycopyrronium, formoterol, and budesonide on coronavirus HCoV-229E replication and cytokine production by primary cultures of human nasal and tracheal epithelial cells. Respir Investig. 2020; 58(3): 155-68.

34. Yamaya M, Nishimura H, Nadine L et al. Formoterol and budesonide inhibit rhinovirus infection and cytokine production in primary cultures of human tracheal epithelial cells. Respir Investig. 2014; 52(4): 251-60.

35. Pleguezuelos E, Del Carmen A, Moreno E et al. The Experience of COPD Patients in Lockdown Due to the COVID-19 Pandemic. Int J Chron Obstruct Pulmon Dis. 2020; 15: 2621-7.

36. Brandt EB, Beck AF, Mersha TB. Air pollution, racial disparities, and COVID-19 mortality. J Allergy Clin Immunol. 2020; 146(1): 61-3.

37. Radzikowska U, Ding M, Tan G et al. Distribution of ACE2, CD147, CD26, and other SARS-CoV-2 associated molecules in tissues and immune cells in health and in asthma, COPD, obesity, hypertension, and COVID-19 risk factors. Allergy. 2020; 75(11): 2829-45.

38. Attaway AA, Zein J, Hatipoglu US. SARS-CoV-2 infection in the COPD population is associated with increased healthcare utilization: An analysis of Cleveland clinic's COVID-19 registry. EClinicalMedicine. 2020; 26:100515.

39. Sin DD. COVID-19 in COPD: A growing concern. EClinicalMedicine. 2020; 26: 100546.

40. Singh D, Agusti A, Anzueto A et al. Global Strategy for the Diagnosis, Management, and Prevention of Chronic Obstructive Lung Disease: the GOLD science committee report 2019. Eur Respir J. 2019; 53(5): 1900164.

41. Pirożyński M. Terapia inhalacyjna $w$ drugiej fali pandemii COVID-19 - czy zmiana zaleceń dotyczacych terapii inhalacyjnej. Alergia. 2020; 3 (w druku).

42. Tran K, Cimon K, Severn $M$ et al. Aerosol generating procedures and risk of transmission of acute respiratory infections 
to healthcare workers: a systematic review. PLoS One. 2012; 7(4): e35797.

43. Fink JB, Ehrmann S, Li J et al. Reducing Aerosol-Related Risk of Transmission in the Era of COVID-19: An Interim Guidance Endorsed by the International Society of Aerosols in Medicine. J Aerosol Med Pulm Drug Deliv. 2020 (w druku).

44. Pirożyński M. Terapia inhalacyjna u dzieci $w$ dobie pandemii COVID-19 ze szczególnym uwzględnieniem nebulizacji. Alergoprofil. 2020; 16(2): 3-7.

45. Pirożyński M, Breborowicz A, Padjas A. Wziewne stosowanie leków w chorobach układu oddechowego. In: Szczeklik A, Gajewski P (ed). Interna Szczeklika. Medycyna Praktyczna, Kraków 2020: 878-84.

ORCID:

M. Pirożýńki - ID - http://orcid.org/0000-0003-3611-4328
Conflict of interests:

None.

Financial support:

None.

Ethics:

The contents presented in this paper are compatible with the rules the Declaration of Helsinki, EU directives and standardized requirements for medical journals.

Copyright: () Medical Education sp. z 0.0. This is an Open Access article distributed under the terms of the Attribution-NonCommercial 4.0 International (CC BY-NC 4.0). License (https://creativecommons.org/licenses/by-nc/4.0), allowing third parties to copy and redistribute the material in any medium or format and to remix, transform, and build upon the material, provided the original work is properly cited and states its license.

Adres do korespondencji

prof. dr hab. n. med. Michał Pirożyński

Centrum Alergologii, Pneumonologii i Medycyny

Ratunkowej, Ośrodek Symulacji CMKP w Warszawie 01-813 Warszawa, ul. Marymoncka 99/103

e-mail: mpirozynski@cmkp.edu.pl 